\title{
The Greens in the 2019 European Elections
}

\author{
Mitya Pearson ${ }^{a}$ and Wolfgang Rüdig ${ }^{b}$ \\ ${ }^{a}$ Department of Political Economy, King's College London, UK \\ ${ }^{\mathrm{b}}$ School of Government and Public Policy, University of Strathclyde, Glasgow, UK \\ Corresponding author:w.rudig@strath.ac.uk
}

Green parties were particularly successful in the May 2019 elections to the European Parliament (EP). 55 Members of the European Parliament (MEPs) representing the European Green Party (EGP) were elected, a major advance on the 37 elected in 2014 and surpassing the previous high of 47 in 2009. This success helped to boost The Greens / European Free Alliance (EFA) parliamentary group to $75^{1}$, from 50 in 2014. With the main centre-left and centre-right groups together failing to command a majority in the Parliament for the first time, the Greens have reason to expect that their influence will increase substantially. Many Green parties will also hope that success in the European elections will have a positive effect on their standing at national level.

\section{The Election Campaign}

The 2014 EP elections had been dominated by austerity and economic crisis; environmental issues were sidelined and the Greens struggled. Following the 2015 refugee crisis and several successful electoral performances, populist and extreme right-wing parties appeared as the major challengers to the mainstream parties, and it was feared that the 2019 EP elections would see a further rise of populist right parties.

Developments in the run up to the elections, however, indicated that conditions might be more encouraging for Greens. Results in local, regional and national elections in Belgium, Germany and Luxembourg in October 2018 saw big increases in support for Green parties, giving rise to the notion of a 'green wave'. Environmental issues also started playing a bigger role in political agenda. In the months leading up to the elections, across Europe, school strikes demanded action on climate change, culminating in Greta Thunberg's address to the EP and her speaking tour of several EU countries in April 2019.

The EGP once again embraced the Spitzenkandidaten (lead candidates) idea and elected Ska Keller of Germany's Alliance '90/The Greens and Bas Eickhout of the Dutch Green Left to lead the campaign. A common European Green manifesto was adopted: 'Time to renew the promise of Europe' summarised in a twelve-point plan headed by the fight against climate change, and also highlighting protecting human rights and democracy, helping refugees, providing job opportunities and securing equal rights for men and women. When the official campaign commenced in March 2019, polling suggested that traditionally dominant centre-right and centre-left parties would lose support and that Greens would 
gain seats. These polls raised the prospect of the Greens being in a good bargaining position in the new EP and helped them to get more media attention.

A late twist to the campaign was the postponement of Brexit, which required the UK to take part in the elections. UK Green parties campaigned on a clear pro-EU platform, hoping to benefit from the Labour Party's ambiguous position on Brexit.

\section{Results}

The Greens' overall achievement masked considerable variation in the performance of national parties. The most startling improvement, with the biggest impact on the size of the Green group, was in Germany where Alliance '90/The Greens almost doubled its share of the vote from $10.7 \%$ to 20.5\%. This represented the Greens' best-ever national result in EP elections, topping the $17.9 \%$ achieved by the Swedish Greens in 1995 (cf. Rüdig 2019). Green parties across northern and western Europe increased their share of the vote and representation, notably in Belgium, Denmark, Finland, France, Ireland, Luxembourg, the Netherlands and the UK. Compared to 2014, the Austrian Greens slipped marginally and the Swedish Greens more substantially (see Table 1).

----- Table 1 around here ---

Compared with this 'green wave' in northern and western Europe, Green parties fared poorly in east-central and southern Europe (cf. Rüdig 2019). The modest progress in east-central Europe in 2014, when the first Green MEPs were elected in Croatia and Hungary, was not repeated; Green parties fell well short of winning representation in both countries. Several Green parties opted to join electoral alliances with other parties to improve their chances. While the Latvian Greens have, since 2002, been part of an alliance with the Farmers Party in all elections, European and national, Green parties in Bulgaria, Croatia, the Czech Republic, Poland and Slovenia joined electoral alliances in European elections after standing on their own in 2014. However, this strategy did not deliver any representation. In Romania, the Green Party failed to collect enough signatures to qualify to be on the ballot paper. ${ }^{2}$ The Lithuanian Farmers and Greens Union (LVŽS) polled $12.6 \%$ and its two MEPs joined the Greens/EFA parliamentary group but the party is not a member of the EGP.

The results in southern Europe paint a similar picture. Here, the strategy of competing as part of electoral alliances is well established and has achieved some success in Portugal and Spain. This time, an internal dispute in the Spanish Green party EQUO over the type of electoral alliance to be joined saw each co-leader sign up for a different group, which resulted in the party not fielding any candidates. Consequently, the Green party of Catalonia (ICV), which again managed to get one MEP elected as part of an electoral alliance with left-wing parties, was the only Green party from southern Europe represented in the EP. Only in Italy, where Green parties had formed an electoral alliance with a small left-wing party, was there a moderate increase in support, albeit insufficient to secure representation. The Portuguese animal rights party (PAN) polled 5.1\% and its one MEP joined the Greens/EFA parliamentary group, although PAN is not a member of the EGP. 


\section{Analysis}

The European Greens celebrated their record overall result in 2019 as a huge success but there are major differences in the strength of the 'green wave' across Europe. Increasing levels of environmental concern can be identified as one factor for Greens success; the increase in the salience of environmental issues started well before 2019 (cf. Toshkov 2019) but accelerated in the months before the elections. According to the Eurobarometer survey of public attitudes, ${ }^{3}$ the share of EU citizens naming 'The environment, climate and energy issues' as one of the two most important issues facing their country increased from $5 \%$ in June 2014 to $20 \%$ in June 2019 . The salience of environmental issues rose particularly dramatically in the Netherlands and Scandinavia. By contrast, eastern and southern European countries show fairly low levels of public interest in the environment.

The rise in environmental concern has thus been most dramatic in the more affluent EU countries. In line with previous EP elections, there continues to be a strong link between gross domestic product per capita ${ }^{4}$ and the Green vote. ${ }^{5}$ Thus, despite the efforts of the European Greens to support Green parties in east-central and southern Europe, the 'green wave' of 2019 is essentially based on the successful mobilisation of voters in traditional northern and western European Green strongholds.

Economic affluence and environmental issue salience are thus major contributors to an explanation of the differences between countries in the degree of Green party success and failure. The link between environmental salience, economic well-being and Green voting is weaker in some countries, however, and there are many nation- and party-specific factors that affect the performance of individual Green parties. Thus, in three countries with high living standards and above average environmental concern - Austria, Malta and Sweden - Green parties lost vote share in 2019 as compared with 2014.

The Austrian Greens had achieved a record result in 2014 with $14.5 \%$ but, mainly due to internal divisions, had collapsed in national parliamentary elections in 2017 to 3.8\% (Buzogány and Scherhaufer 2018). Having entered the 2019 European Elections from a position of weakness, the Greens did well to come close to their 2014 results. Internal divisions also contributed to the poor performance of the Maltese Greens. Founder member and former party leader Arnold Cassola, whose popularity had been a major factor in the party's best ever election result $19.3 \%$ in the European Elections of 2004), left the party in the middle of the election campaign over a dispute about the issue of abortion, and ran as an independent. The Swedish Greens can look back on a long history of representation at national and European level but, despite a significant pre-election rise in environmental concern, the party's vote share slipped by almost four percentage points compared to 2014. As members of a minority coalition government with the Social Democrats since 2014, the Swedish Greens have taken some particularly painful decisions, notably on immigration; their losses probably reflect some voters' disappointment with the party's role in government. 
Difficult compromises made in government but unpopular with supporters have been a problem for Green parties in the past, but electoral punishment does not inevitably follow. In Luxembourg, the Greens have been in government with Liberals and Social Democrats since 2013 but avoided any major controversies and continued to enjoy popular support. In Greece, where the Greens formed an electoral alliance with SYRIZA in 2015 and were represented in government with a junior environment minister, the profile of the party remained very low and appears to have had little impact on its European election performance.

Campaigning in EP elections as opposition parties again proved advantageous: all the parties making major electoral advances (in Germany, Finland, Ireland, France, the UK and Belgium) were not involved in national government at the time. The German Greens benefited from not having been in federal government since 2005, combined with the election of a new, charismatic leadership. The German success was also based on an electoral strategy of strict opposition to the political agenda of the populist far right on immigration and other issues, which attracted support from both former Social Democrat and Christian Democrat voters. In Britain, too, the Greens may have benefited from their principled opposition to the populist right, with their clear support for the UK to remain in the EU attracting many former Labour voters. In Belgium, France, Ireland, and Italy, losses by centre-left parties were also accompanied by increased support for Green parties. However, in Denmark, Finland and the Netherlands, where Green parties made significant gains, Socialist/Social Democratic parties also increased their vote shares.

\section{Conclusions}

The 2019 EP elections were the first for some time in which environmental issues played an important role. Will these elections be a turning point for Green parties, introducing a period of increasing political importance at national level too? EP elections are generally regarded as 'secondorder elections' in which voters are more willing than in national elections to support small parties. Support in EP elections has not in the past necessarily translated into success at national level.

Nevertheless, there are indications that the EP elections have strengthened the position of some Green parties. With Green parties in 11 countries achieving double-digit shares of the vote, even a slightly lower share in national elections will not only ensure continued representation but also a higher probability of their participating in coalition governments. Following the EP elections, several Green parties either joined a national coalition government (Finland) or entered coalition negotiations (Austria, Belgium). In Denmark, the Socialist People's Party, as part of the 'red bloc', entered an agreement to support a Social Democratic minority government. In Germany, the Greens maintained a poll rating just above the $20 \%$ mark throughout 2019 and are widely expected to be a partner in the next German coalition government.

The lessons of 2019 are less clear for eastern and southern Europe. The strategy of forming electoral alliances is a promising way for small green parties to enhance their chances of winning representation. The Polish case demonstrates the potential: in national parliamentary elections in October 2019, Polish Greens won three seats as part of a Civic Coalition with two centrist parties. 
However, green parties depending on electoral alliances remain vulnerable. One successful exponent of this strategy, the Catalan Greens (ICV), for many years won representation at all levels as part of various electoral alliances but, after winning a seat in the EP election, the party was dissolved in July 2019, ostensibly for financial reasons, and was absorbed by the Catalonia in Common party. Other political forces, in this case the anti-austerity movement and the movement for Catalan independence, reshaped the party system to sideline and subsume a green party (Saura 2019). This provides a forceful illustration of the challenges facing green parties seeking to survive as distinct political entities in countries where environmental issues are very low on the political agenda. 
Table 1: European Elections 2019 results

\begin{tabular}{|c|c|c|c|c|c|}
\hline Country & EGP Member Party & $\%(2019)$ & $\begin{array}{l}\text { Change } \\
\text { since } \\
2014\end{array}$ & $\begin{array}{l}\text { Green MEPs } \\
2019\end{array}$ & $\begin{array}{l}\text { Change since } \\
2014\end{array}$ \\
\hline Austria & $\begin{array}{l}\text { The Greens - The Green } \\
\text { Alternative }\end{array}$ & 14.1 & -0.4 & 2 & -1 \\
\hline Belgium & $\begin{array}{l}\text { Green } \\
\text { ECOLO }\end{array}$ & $\begin{array}{l}7.6 \\
7.6\end{array}$ & $\begin{array}{l}+0.9 \\
+3.3\end{array}$ & $\begin{array}{l}1 \\
2\end{array}$ & $\begin{array}{l}0 \\
+1\end{array}$ \\
\hline Bulgaria & $\begin{array}{l}\text { The Green Movement* } \\
\text { Green Party of Bulgariat }\end{array}$ & $\begin{array}{l}(6.1) \\
\text { DNP }\end{array}$ & $\begin{array}{l}+5.5] \\
-0.4\end{array}$ & $\begin{array}{l}0 \\
0\end{array}$ & $\begin{array}{l}0 \\
0\end{array}$ \\
\hline Croatia & $\begin{array}{l}\text { Croatian Sustainable } \\
\text { Development }(\mathrm{ORaH}) *\end{array}$ & (1.8) & {$[-7.7]$} & 0 & -1 \\
\hline Cyprus & $\begin{array}{l}\text { Movement of Ecologists } \\
\text { - Citizens' Cooperation* }\end{array}$ & (3.3) & $(-4.4)$ & 0 & 0 \\
\hline $\begin{array}{l}\text { Czech } \\
\text { Republic }\end{array}$ & Green Party (SZ)* & $(11.7)$ & {$[+7.9]$} & 0 & 0 \\
\hline Denmark & $\begin{array}{l}\text { Socialist People's Party } \\
\text { (SF) }\end{array}$ & 13.2 & +2.2 & 2 & +1 \\
\hline Estonia & Estonian Greens & 1.8 & +1.5 & 0 & 0 \\
\hline Finland & Green League & 16.0 & +6.7 & 2 & +1 \\
\hline France & $\begin{array}{l}\text { Europe Ecology - The } \\
\text { Greens (EELV)* }\end{array}$ & $(13.5)$ & $(+4.5)$ & 9 & +3 \\
\hline Germany & Alliance '90/The Greens & 20.5 & +9.9 & 21 & +10 \\
\hline Greece & Ecologist Greens & 0.9 & 0.0 & 0 & -1 \\
\hline Hungary & $\begin{array}{l}\text { Politics can be different } \\
\text { (LMP) }\end{array}$ & 2.2 & -2.8 & 0 & -1 \\
\hline Ireland & $\begin{array}{l}\text { Green Party - } \\
\text { Comhaontas Glas }\end{array}$ & 11.4 & +6.5 & 2 & +2 \\
\hline Italy & $\begin{array}{l}\text { Federation of the } \\
\text { Greens / Greens (South } \\
\text { Tyrol)* }\end{array}$ & (2.3) & {$[+1.4]$} & 0 & 0 \\
\hline Latvia & $\begin{array}{l}\text { Latvian Green Party } \\
\text { (LZP)*+† }\end{array}$ & $(5.3)$ & $(-3.0)$ & 0 & 0 \\
\hline Lithuania & - & - & - & - & - \\
\hline Luxembourg & The Greens & 18.9 & +3.9 & 1 & 0 \\
\hline Malta & Alternative Democracy & 0.7 & -2.3 & 0 & 0 \\
\hline Netherlands & Green Left & 10.9 & +3.9 & 3 & +1 \\
\hline Poland & Green Party* & (38.5) & {$[+38.3]$} & 0 & 0 \\
\hline Portugal & $\begin{array}{l}\text { Ecologist Party 'The } \\
\text { Greens' (PEV)* }\end{array}$ & (6.9) & $(-5.8)$ & 0 & 0 \\
\hline Romania & Green Party (PV) & DNP & -0.3 & 0 & 0 \\
\hline Slovakia & - & - & - & - & - \\
\hline Slovenia & $\begin{array}{l}\text { Youth Party - European } \\
\text { Greens* }\end{array}$ & (1.7) & - & 0 & 0 \\
\hline Spain & $\begin{array}{l}\text { EQUO } \\
\text { Initiative for Catalonia } \\
\text { Greens (ICV)* }\end{array}$ & $\begin{array}{l}\text { DNP } \\
(10.1) \\
\end{array}$ & $\begin{array}{l}-1.9 \\
(+0.1)\end{array}$ & $\begin{array}{l}0 \\
1 \\
\end{array}$ & $\begin{array}{l}-1 \\
0\end{array}$ \\
\hline Sweden & $\begin{array}{l}\text { Environment Party - the } \\
\text { Greens }\end{array}$ & 11.5 & -3.9 & 2 & -2 \\
\hline
\end{tabular}




\begin{tabular}{|l|l|l|l|l|l|}
\hline UK & $\begin{array}{l}\text { Green Party of England } \\
\text { and Wales (GPEW) } \\
\text { Scottish Green Party } \\
\text { (SGP) }\end{array}$ & 10.9 & +4.0 & 7 & +4 \\
$\begin{array}{l}\text { Green Party in Northern } \\
\text { Ireland }\end{array}$ & 0.8 & +0.1 & 0 & 0 \\
\hline
\end{tabular}

DNP = Did not participate in 2019 European elections

() Results for electoral alliances involving one or more EGP member parties

[] Change of vote from individual Green Party candidacy in 2014 to electoral alliance candidacy in 2019

*Electoral alliances:

Bulgaria: Democratic Bulgaria (Yes, Bulgaria; Democrats for a Strong Bulgaria; The Green Movement) Croatia: Croatian Sustainable Development; We can - Political Platform; New Left.

Cyprus: Movement of Ecologists - Citizens' Cooperation; Citizens' Alliance.

Czech Republic: Mayors and Independents (STAN); TOP 09; Green Party; Liberal-Environmental Party; and regional movements.

France: Europe Ecology - The Greens; Independent Ecologist Alliance; Regions and Peoples with Solidarity.

Italy: Green Europe (The Federation of the Greens; Verdi-Grüne-Vërc (Greens of South Tyrol); Green Italy; Possibile).

Latvia: Union of Greens and Farmers (Latvian Green Party; Latvian Farmers Union).

Poland: European Coalition (Civic Platform; Polish People's Party; Democratic Left Alliance; Modern; Greens).

Portugal: Unitary Democratic Coalition (Portuguese Communist Party; Ecologist Party "The Greens"). Slovenia: Connect (Youth Party - European Greens; Solidarity Party; Workers Party of Slovenia; List of Cyclists and Pedestrians; People's Front; and various local groups and NGOs).

Spain: United We Can Change Europe (Podemos; United Left; Catalonia in Common (which includes Initiative for Catalonia Greens); Barcelona in Common).

† The Green Party of Bulgaria disaffiliated from the EGP in July 2019.

+† The Latvian Green Party was expelled from the EGP in November 2019.

Sources: National election institutions; https://resultats-elections.eu/;

https://europeangreens.eu/2019results ; UK: own calculation of UK share of the vote of each party based on Fella et al. 2019 and http://www.eoni.org.uk/Elections/Election-results-andstatistics/Election-results-and-statistics-2003-onwards/Elections-2019 ; www.europeangreens.eu 


\section{References}

Buzogány, A. and Scherhaufer, P. 2018. Austrian Greens: from pyrrhic presidential victory to parliamentary exit. Environmental Politics 27 (3):566-571. doi.org/10.1080/09644016.2018.1438793

Fella, S., Uberoi, E. and Cracknell, R. 2019. European Parliament Elections 2019: results and analysis. (Briefing Paper No 8600) London: House of Commons Library.

Rüdig, W. 2019. Green parties and elections to the European Parliament, 1979-2019. In: L. Ward with J. Brady, eds. Greens for a Better Europe. London: London Publishing Partnership, 3-48.

Saura, V. (2019) ¿Había que 'matar' a Iniciativa per Catalunya? http://catalunyaplural.cat/es/habiaque-matar-a-iniciativa-per-catalunya/ [accessed 3 December 2019]

Toshkov, D. 2019. Public salience of the environment in the EU, 2003-2018.

https://twitter.com/DToshkov/status/1134360972108455936 [accessed 31 May 2019]

\footnotetext{
${ }^{1}$ This includes the imprisoned Oriol Junqueras i Vies of the Republican Left of Catalonia (ERC) who has been prevented from taking up his seat by the Spanish Government, with a case before the Court of Justice of the EU pending (December 2019).

${ }^{2}$ We are grateful to Maria Mitaev for information on the case of the Green Party (PV) in Romania.

${ }^{3}$ All data reported are based on the Standard Eurobarometer reports, https://ec.europa.eu/commfrontoffice/publicopinion/index.cfm/Survey/index\#p=1\&instruments=STANDARD [accessed 3 December 2019]

${ }^{4}$ GDP per capita in PPS (Purchasing Power Standards), 2018, source: EUROSTAT, https://ec.europa.eu/eurostat/databrowser/view/tec00114/default/table?lang=en (accessed 3 December 2019].

${ }^{5}$ For the 18 countries in which Green parties stood on their own, the correlation co-efficient is $r=0.682$ $(p<0.000)$. However, even if we include the results for electoral alliances (except for Poland, where all centreleft parties formed an alliance polling 38.5\%), the correlation co-efficient is only slightly lower at $r=0.672$ $(p<0.000 ; N=27)$. In the European Elections of 2014, the correlation between the Green vote (excluding electoral alliances) and GDP per capita was $r=0.703(p<0.000, N=24)$.
} 